\title{
THE FACILITATION OF PROFESSIONAL VALUES AMONGST STUDENT NURSES IN THE NORTH-WEST PROVINCE
}

\section{Mogodi}

M Cur

Postgraduate student, Department of Nursing Science, Rand Afrikaans University

\section{K Jooste}

D Litt et Phil

Associate Professor, Department of Nursing Science, Rand Afrikaans University

Corresponding author: kjo@edcur.rau.ac.za

\author{
AC Botes (late) \\ D Cur \\ Professor, Department of Nursing Science, Rand Afrikaans University
}

Keywords: professional values; caring; learning strategies; domains of learning; assessment; North-West Province, South Africa

\begin{abstract}
The purpose of this study was to formulate guidelines to facilitate the internalisation of professional values in student nurses in order to enable them to become caring registered nurses. To realise this goal, the researcher followed a quantitative, qualitative, descriptive, exploratory and contextual approach. In Phase One of the study, data was collected from the nurse educators through focus group interviews and from the student nurses by means of written narratives. The groups separately described their perceptions about those professional values they deemed important for nursing and how these professional values should be taught to student nurses in order to make them caring registered nurses. Conceptualisation was undertaken in Phase Two. Phase Three focused on document analysis to evaluate whether the identified professional values and teaching strategies were reflected in the college curriculum. Guidelines were formulated in the last phase. These guidelines could be used by the nurse educators to facilitate caring among students as registered nurses. Some of the identified professional values and teaching strategies were indeed reflected in the college curriculum. However, the evaluation of tests and examinations did not seem to confirm that these professional values were taught, nor that the teaching strategies had indeed been used. The guidelines highlighted that the values identified should form part of the college curriculum.
\end{abstract}

\section{OPSOMMING}

Die doel van hierdie studie was om riglyne te formuleer om die internalisering van professionele waardes in studenteverpleegkundiges te fasiliteer wat hulle in staat sal stel om praktisyns wat omgee, te word. Om hierdie doel te bereik, het die navorser ' $n$ kwantitatiewe, kwalitatiewe, verkennende, beskrywende en kontekstualiserende benadering gevolg. In Fase Een van die studie, is data deur middel van fokusgroeponderhoude met verpleegopvoeders en geskrewe verhale/sketse deur studenteverpleegkundiges versamel. Hierdie groepe is afsonderlik gevra om hulle persepsies van die belangrike professionele waardes vir die verpleegberoep te beskryf asook hoe hierdie professionele waardes aan studenteverpleegkundiges onderrig moet word om van hulle praktisyns wat omgee, te maak. Konseptualisering is in Fase Twee onderneem. Fase Drie het gefokus op dokumentanalise om vas te stel of die professionele waardes en onderrigstrategieë wat geïdentifiseer is, in die kollegekurrikulum gereflekteer word. Riglyne wat verpleegopvoeders kan gebruik om "omgee" by studente as verpleegpraktisyns te fasiliteer is in Fase Vier van die studie geformuleer. Sommige van die geïdentifiseerde professionele waardes en onderrigstrategieë word wel in die kurrikulum van die kollege gereflekteer. Nieteenstaande het die evaluering van 
toetse en eksamenvraestelle nie bevestig dat professionele waardes wel onderrig word nie, of dat die onderrigstrategieë wel toegepas word nie. Die riglyne het aangedui dat die geïdentifiseerde waardes deel van die kollegekurrikulum moet wees.

\section{INTRODUCTION}

The primary goal in nursing is to provide the best care to each individual and therefore nurses need to know what they value, as this influences their relationships and the ways in which they practise nursing as a profession.

According to Haegert (2001:29), nursing is a profession that has been mandated by society to serve its health needs. This could to a certain extent make it mandatory for nurses to revisit their professional values continually in order to prevent society from withdrawing this mandate.

Caring has been identified as the heart, the central theme, the focus and the essence of the nursing profession (Brink, 1990:38; Oermann, 1991:53; Searle \& Pera 1993:94). "Caring" is outlined as the most basic of all the nursing professional values (Pera \& Van Tonder, 1996:9). This makes it obligatory for registered nurses in health services, nurse educators in the nursing college and nursing service managers to instil caring values in students. This is important as the failure of nurses to care nullifies or defeats the purpose of nursing (Brink, 1990:39). The lack of addressing professional values such as caring in nursing curricula could defeat the purpose of nursing.

Booyens (1998:585) believes that it is important to clarify the concept of "care", as this lays the foundation for instilling a culture of caring into the registered nurses of a caring profession. According to Haegert (2001:29), people's knowledge and understanding of this concept will definitely have an impact on how they execute caring actions. Haegert (2001:28) believes that "caring is a natural capacity essential for members of a caring profession". It is a humanistic activity provided by registered nurses to the patients, their relatives and visitors in health centres, such as hospitals and clinics. Caring should be grounded in humanistic values such as kindness, empathy and concern for others as well as altruistic values that bring meaning to one's life through relationships with other people (Watson, 1985:12). Nursing curricula should address the caring nature of nursing.

\section{PROBLEM STATEMENT}

The lack of caring by nurses could reflect negatively on nurse educators, on registered nurses as role models and on the nursing education system, if it places more emphasis on knowledge and clinical skills competencies than on values and attitudes. Brink (1990:41) states that the focus on teaching and assessment appears mostly to be on cognitivetechnical outcomes/competencies, resulting in the production of clinically competent registered nurses who lack compassion and caring. This clearly shows that the focus on the preparation of caring registered nurses is a factor that needs to be investigated. Registered nurses should acknowledge that the quality of 'caring' has a complex set of affective, cognitive and interactional elements, which should be put into purposeful action between themselves as educators and their students (Minnaar, 2002:32).

Health care consumers are and have been voicing dissatisfaction about the care that they receive from health care providers, especially from the nurses in the local hospitals and clinics (Webb, Pesata, Bower, Gill \& Pallija, 2001:416). The North-West Province has not been spared this outcry of dissatisfaction. The researcher has, from practical experience, become aware that the feedback by patients on leaving the hospitals and clinics in this province indicates patient dissatisfaction with the lack of caring (affective domain) among nurses who render nursing care.

Nurses could enter the profession already possessing preconceived societal values about nursing, which they have acquired from society. Brink (1990:42) concurs with this notion and adds that for nurses to be able to care, they need to exchange the "outsider's" view of what nursing is perceived to be, with the "insider's" view of what nursing really is. To be a caring registered nurse, one needs to internalise the values of the profession. Students could attain this firstly by 
accepting and internalising professional values addressed in the nursing curricula and, secondly, by acting these values out in the everyday work life. By internalising professional values, these professional values could be made their own (Quinn, 1995:279).

It is evident that the process of facilitation of professional values among nurses needs to be addressed in all nursing education settings. The means by which this could be promoted and restored in one nursing college in the North-West Province of South Africa is to be explored in this study. In the said setting, it was unclear which professional values nurse educators and students perceived as being important for nursing and how these professional values should be taught to student nurses in order to make them caring registered nurses. It was also unknown whether the identified professional values and teaching strategies were reflected in the college curriculum.

\section{RESEARCH PURPOSE AND OBJECTIVES}

The purpose of the study was to develop guidelines to improve the facilitation of the internalisation of professional values among student nurses at a nursing college in the North-West Province, in order to help them become caring registered nurses, and to reduce the problem of a non-caring attitudes among nurses. To realise this purpose, the following objectives were stated:

- to explore and describe the perceptions of nurse educators and student nurses about the professional values that should be taught at a nursing college (Phase One);

- to explore and describe how these values could be taught in order to help student nurses to become caring registered nurses (Phase Two);

- to evaluate whether professional values are reflected in the college curriculum, tests and examination papers (Phase Three); and

- to develop guidelines to facilitate the internalisation of professional values in student nurses (Phase Four).

\section{DEFINITION OF CENTRAL CONCEPTS}

\section{Professional values}

A value frequently arises from a person's background, tradition and philosophy. The inner meaning of an ac- tion or an attitude refers to a person's values. Weis and Schank (1995:366) define professional values as "standards for action accepted and identified by registered nurses". These values could provide a framework for evaluating decisions and beliefs that influence the behaviour of the registered nurses, as these individuals have capabilities to choose what they regard as worthy and important for making decisions.

\section{Caring}

A professional value is expressed through conduct, feelings, imagination, knowledge and action (Pera \& Van Tonder, 1996:5,9). In nursing, the most basic of professional values should be that of caring. This caring value serves as a springboard for the application of all the other values inherent in a relationship in the nursing environment. Caring combines justice, equity and respect with genuine concern. When students feel valued and appreciated by the educator or registered nurse, they are motivated to give their best when they care for patients/clients.

\section{Student nurse}

For the purposes of this study, the researcher defined the student nurse as a second-, third- or final fourthyear student that is registered with the particular nursing college in the North-West Province. Students are registered with the South African Nursing Council (SANC) and are studying towards the diploma in a comprehensive course, as in Regulation 425 as amended. This regulation relates to the approval of and the minimum requirements for the education and training of a nurse (general, psychiatric and community) and midwife leading to registration

\section{Internalisation of professional values}

This is a process whereby a student nurse makes the professional values, learnt from the nurse educators, "his/her own" and internalises the clinical aspect of being a caring nurse (Naudé, Meyer \& Van Niekerk, 2000:117).

\section{Facilitation}

This refers to a mutual involvement/interaction between the nurse educator and the student nurse with the purpose of mobilising their resources, knowledge, skills, attitudes and values in order to promote a caring environment and to restore the caring ethos in nursing. It is a dynamic process aimed at aiding, or 
facilitating the internalisation of professional values among nurses (Department of Nursing Science, Rand Afrikaans University, 2001:7).

\section{RESEARCH DESIGNS AND METHODS}

Quantitative and qualitative research approaches were selected for this study.

\section{Phase One}

This phase focused mainly on the collection of data. It led to exploring and describing the perceptions of nurse educators and student nurses about (i) which professional values should be taught to student nurses to make them caring registered nurses, and (ii) how the internalisation of these values could be facilitated in student nurses to make them caring registered nurses. Data from these two groups were collected separately and both groups provided data in their real setting, without coercion and in non-threatening environments. The respondents were able to provide data that enabled the researcher to realise the study objectives.

\section{Data collection}

Data from the nurse educators were collected through focus group interviews, which were tape-recorded. The guidelines for conducting focus group interviews of Stewarts and Shamdasami (1990:88) and De Vos (1998:320) were followed. The college had a population of 23 nurse educators who were registered with the South African Nursing Council and had been with the college for two years or longer. All these nurse educators were responsible for both the theoretical and clinical accompaniment of students. All 23 nurse educators were selected for the sample.

Data from the student nurses were collected by means of a written narrative. A written narrative/spontaneous sketch is a descriptive method in which the respondent is asked for his/her personal description of phenomena of interest to the researcher (Creswell, 1994:159; Giorgi, 1985:442). This allows the participants to respond with minimal restrictions to all answers and the meaning of answers (Kerlinger, 1986:442).

The population consisted of approximately 200 students in the college. A sampling of 168 students was performed. Students who were registered with the nursing college for the diploma in comprehensive nursing in their second to fourth year of study were purposively selected. The rationale for this selection was that these students had been with the nursing college for at least one year and should have experienced and viewed professional nursing practice. Students that attended classes at the college in the last semester of the year, were asked to participate in the study. Students attend classes on different days according to year of training and language preference. This made probability sampling a rather difficult choice for the researcher and it was decided to use purposive selection. The students were assured of anonymity and confidentiality. All the students voluntarily agreed to participate in the study and gave informed consent.

\section{Data analysis of Phase One}

The qualitative data analysis of Phase One involved the examination of words rather than numbers. Coding is used to organise data collected in written documents. The following adapted steps of Tesch in De Vos (2001:343-344) were used in analysing the data obtained:

- reading through the interviews and narratives to obtain a picture of the whole topic;

- looking for themes;

- making a list of topics and grouping similar topics together;

- finding the most descriptive wording in the topics and turning them into categories; and

- verifying the selected themes through reflection on the data discussing them with an expert in the field of ethos and professional practice.

The data of the participants were constantly compared in the determination of the final main guidelines for the facilitation of professional values among nurses (Brink, 2001:192-193). The data analysis from Phase One led to the initiation of the literature study undertaken in Phase Two.

\section{Phase Two}

This phase dealt with conceptualisation. Literature was reviewed to determine:

- the important professional values for nursing; and

- what teaching strategies would facilitate the internalisation of these professional values by 


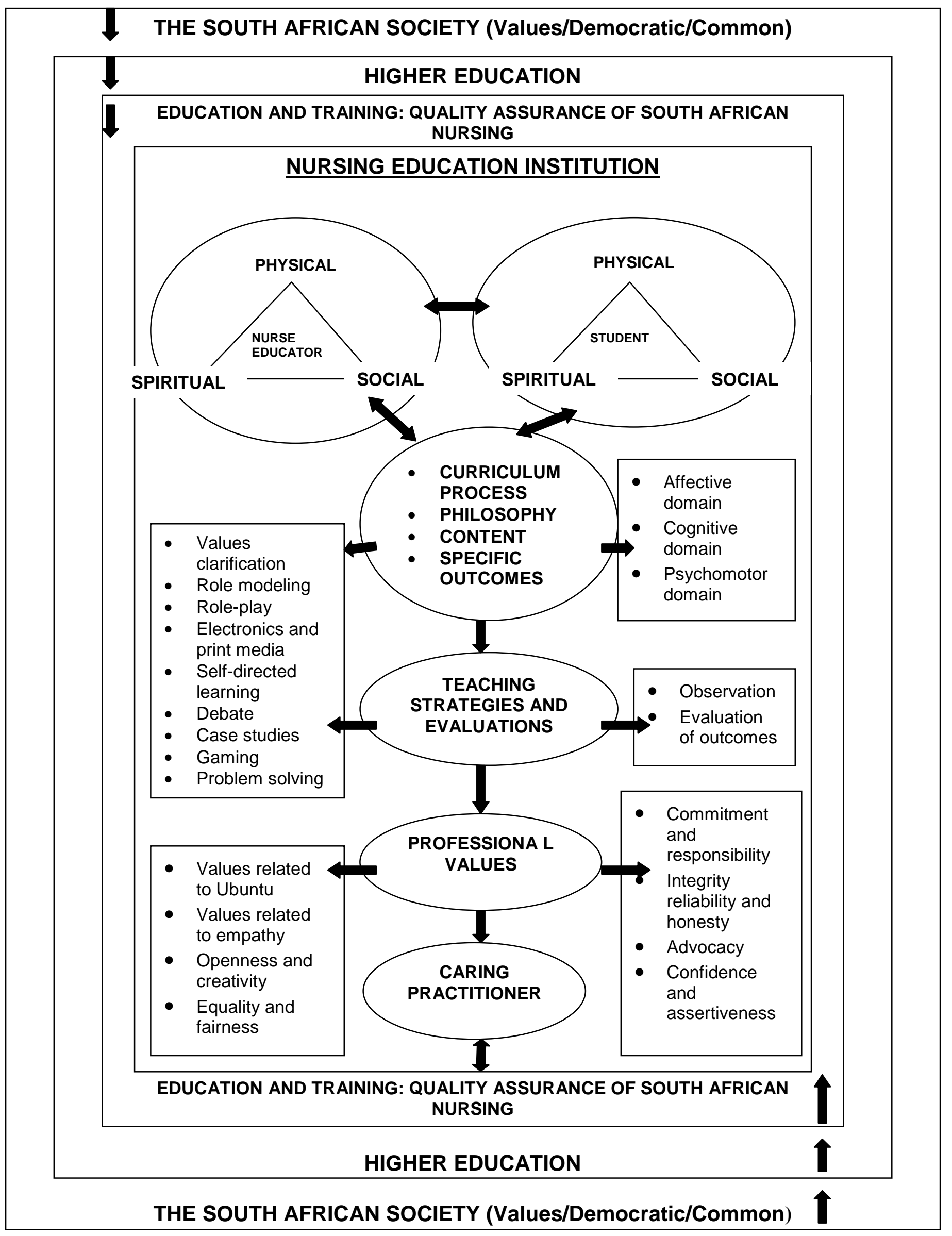

Figure 1: $\quad$ Conceptual framework 
student nurses, in order to make them caring registered nurses.

Based on the data obtained from Phases One and Two, standards and criteria were formulated for inclusion in a checklist (table 1). The developed checklist was for the purposes of document analysis in Phase Three. The checklist was developed for the assessment of the nursing college curriculum, tests and examination papers.

\section{Phase Three}

This phase focused on document analyses. The documents analysed during this phase were the college curriculum, tests and examination papers used for formative and summative assessment during second- to fourth-year nursing training. These were analysed quantitatively by means of a checklist that was developed during Phase Two of the design. These document analyses were undertaken to determine whether the identified professional values and appropriate teaching strategies were reflected in these documents.

\section{Phase Four}

This phase described the guidelines to be used by the nurse educators and student nurses in facilitating the internalisation of professional values in student nurses to make caring registered nurses. The three phases of the design described above were integrated to develop these guidelines.

\section{ETHICAL CONSIDERATIONS}

The researcher obtained consent from the ethics committee of the Rand Afrikaans University and the authorities of the Nursing College to conduct the research study. The respondents were informed about the benefits of the study, and the right to withdraw at any stage of the study. The respondents were asked to give their contributions anonymously, without providing names. They gave their informed consent to participate in the study and participated voluntarily.

\section{FINDINGS AND DISCUSSIONS}

\section{Phase One}

Professional values underlying caring were identified as values related to Ubuntu, such as values related to empathy, openness creativity, equality, fairness, commitment, responsibility, integrity, reliability, honesty, advocacy, confidence and assertiveness. The teaching strategies described were clarification of values, role modelling, role-play, electronic and print media, selfdirected learning approaches, debate, case studies, gaming and problem solving. The important values and strategies identified in Phase One formed the basis for the conceptualisation and literature study in Phase Two. This phase thus addressed what it set out to achieve in Objectives One and Two of the study and common values and teaching strategies were identified and described.

\section{Phase Two}

The literature reviewed concurred with what both groups identified and described as appropriate values and teaching strategies to facilitate caring in registered nurses in Phase One. However, the literature highlighted difficulties in teaching and assessing aspects falling within the affective domain (Naudé et al. 2000:109; Brink, 1990:41). According to Andrusyszyn (1998:76), values form part of the affective domain. This poses a challenge to the nurse educators of this particular nursing college. Bloom's taxonomy is regarded as the most suitable choice in describing how teaching and assessment in the affective domain should be conducted (Quinn, 1995:240). The literature also highlighted that the nurse educators' training focused on technical-cognitive competencies, with little or no regard for affective competencies. This further justifies the need to formulate guidelines for the nurse educators of the nursing college to address the current problem of noncaring attitudes among nurses. Following conceptualisation, standards and criteria were described in the form of a checklist (table 1).

\section{Phase Three}

This was done quantitatively, as depicted in the checklist, and a brief justification of the findings was done with the aid of a rating scale with scores ranging 
Table 1: Checklist for the assessment of the nursing college curriculum, tests and examination papers

\begin{tabular}{|l|l|l|l|l|}
\hline \multicolumn{2}{|l|}{ ITEMS } & $\mathbf{0}$ & $\mathbf{1}$ & $\mathbf{2}$ \\
\hline 1. The purpose of the program reflects the ... & & & $\checkmark$ \\
\hline 1.1 & cognitive domain & & & $\checkmark$ \\
\hline 1.2 & psychomotor/technical domain & & $\checkmark$ & \\
\hline 1.3 & affective domain & & \\
\hline
\end{tabular}

2. The mission, vision statement and philosophy of the nursing college reflect the following values underlying caring:

\begin{tabular}{|l|l|l|l|l|}
\hline 2.1 & $\begin{array}{l}\text { Values related to ubuntu, such as respect of self and respect of human } \\
\text { dignity }\end{array}$ & & $\checkmark$ & \\
\hline 2.2 & Values related to empathy & $\checkmark$ & & \\
\hline 2.3 & Openness and creativity & & & $\checkmark$ \\
\hline 2.4 & Equality and fairness & & & $\checkmark$ \\
\hline 2.5 & Commitment, responsibility and accountability & & & $\checkmark$ \\
\hline 2.6 & Integrity, reliability and honesty & $\checkmark$ & & \\
\hline 2.7 & Advocacy & $\checkmark$ & & \\
\hline 2.8 & Confidence and assertiveness & & $\checkmark$ & \\
\hline 3. & objectives of the nursing colege reflect the valus that faclitate & & \\
\hline
\end{tabular}

3. The objectives of the nursing college reflect the values that facilitate caring:

\begin{tabular}{|l|l|l|l|l|}
\hline 3.1 & $\begin{array}{l}\text { Values related to ubuntu, such as respect of self and respect for human } \\
\text { dignity: }\end{array}$ & & $\checkmark$ & \\
\hline 3.2 & Values related to empathy & $\checkmark$ & & \\
\hline 3.3 & Openness and creativity & $\checkmark$ & & \\
\hline 3.4 & Equality and fairness & & $\checkmark$ & \\
\hline 3.5 & Commitment, responsibility and accountability & & & $\checkmark$ \\
\hline 3.6 & Integrity, reliability and honesty & & $\checkmark$ & \\
\hline 3.7 & Advocacy & $\checkmark$ & & \\
\hline 3.8 & Confidence and assertiveness & $\checkmark$ & & \\
\hline
\end{tabular}

4. The college curriculum is based on the learning/teaching theories that reflect the following domains to facilitate caring in nurses:

\begin{tabular}{|l|l|l|l|l|}
\hline 4.1 & Affective domain & & $\checkmark$ & \\
\hline 4.2 & Cognitive domain & & & $\checkmark$ \\
\hline 4.3 & Psychomotor/technical domain & & & $\checkmark$ \\
\hline
\end{tabular}

5. The specific outcomes formulated for the following year levels reflect values that facilitate caring in nurses:

\begin{tabular}{|l|l|l|l|l|}
\hline 5.1 & Level One & & $\checkmark$ & \\
\hline 5.2 & Level Two & & $\checkmark$ & \\
\hline
\end{tabular}




\begin{tabular}{|l|l|l|l|l|}
\hline \multicolumn{2}{|l|}{ ITEMS } & $\mathbf{0}$ & $\mathbf{1}$ & $\mathbf{2}$ \\
\hline 5.3 & Level Three & & $\checkmark$ & \\
\hline 5.4 & Level Four & & & $\checkmark$ \\
\hline $\mathbf{5 .}$ The learning content of the curriculum reflects the following domains of learning: \\
\hline 6.1 & Cognitive domain & & & $\checkmark$ \\
\hline 6.2 & Affective domain & & $\checkmark$ & \\
\hline 6.3 & Psychomotor/technical domain & & & $\checkmark$ \\
\hline 6.
\end{tabular}

6. The curriculum reflects the following teaching/learning strategies that facilitate caring in nurses:

\begin{tabular}{|l|l|l|l|l|}
\hline 7.1 & Values clarification & & & $\checkmark$ \\
\hline 7.2 & Role modelling & $\checkmark$ & & \\
\hline 7.3 & Role-play & & & $\checkmark$ \\
\hline 7.4 & Electronic and print media & $\checkmark$ & & \\
\hline 7.5 & Self-directed learning approaches & & & $\checkmark$ \\
\hline 7.6 & Debate & & & $\checkmark$ \\
\hline 7.7 & Case studies & & & $\checkmark$ \\
\hline 7.8 & Gaming & & & $\checkmark$ \\
\hline 7.9 & Problem solving & & & $\checkmark$ \\
\hline 7.9
\end{tabular}

7. The formative and summative assessment conducted in the college reflects the use of a variety of assessment strategies/methods that evaluate whether caring took place:

\begin{tabular}{|l|l|l|l|l|}
\hline 8.1 & $\begin{array}{l}\text { The test papers and clinical practicals conducted in the college reflect } \\
\text { the use of observation as a strategy/method to assess whether caring } \\
\text { took place. }\end{array}$ & & & \\
\hline 8.2 & $\begin{array}{l}\text { The test papers and clinical practicals conducted in the college reflect } \\
\text { the use of evaluation of outcomes (by looking at something the learner } \\
\text { has done after the activity has been completed) to assess whether } \\
\text { caring took place. }\end{array}$ & $\checkmark$ & & \\
\hline
\end{tabular}

8. The questions in the test and examination papers reflect the following aspects of the values:

\begin{tabular}{|l|l|l|l|l|}
\hline 9.1 & Cognitive aspect of the values & $\checkmark$ & & \\
\hline 9.2 & Psychomotor aspect of the values & & $\checkmark$ & \\
\hline 9.3 & Affective aspect of the values & $\checkmark$ & & \\
\hline
\end{tabular}

0 = non-compliant, 1 = partially compliant, 2 = compliant

from 0 to 2. Zero indicated non-compliance, one indicated partial compliance and two indicated compliance with the criteria. The average results are reflected in table 1.

During the assessment of the examination and test papers, it became clear that the affective aspects of the values reflected in the nursing curriculum were neither taught nor evaluated/assessed adequately in the test and examination papers. This phase also highlighted and drew the researcher back to the research problem statement in that this could have a direct link to the fact that emphasis is placed on technical and cognitive competencies and not on the affective domain competencies. 


\section{Phase Four}

The following guidelines were suggested, based on the empirical data (Phase One of the design) and the conceptualisation (Phase Two of the design), as well as the quantitative and qualitative document analysis (Phase Three of the design).

\section{Nursing education}

- Nurse educators should use the checklist periodically as a self-assessment tool.

- Nurse educators, as important implementers of these guidelines, must receive regular in-service training on these teaching strategies.

- Identified professional values are to be taught to student nurses to facilitate the internalisation thereof by them in order to make them caring registered nurses.

- Values come from a sense of discrimination of what is right and not right for an individual, and the nursing pledge constitutes a code of conduct and values according to which nurses should choose to practise (Smith, 2000:84).

\section{Curriculum}

- Professional values should be spelled out clearly and form part of the curriculum document. It should be stated that this is to further "the ethos of caring", as this seems particularly to have been eroded in the nursing profession (Smith, 2000:86). Tutors should be aware that students would not be influenced by values unless they agreed with them.

- The identified professional values should be incorporated in the purpose of the diploma qualification, so that curriculum planners and developers do not lose sight of these values, as the "purpose" usually informs the other aspects of the curriculum.

- The curriculum must, among others, clearly indicate and be inclusive, but not exhaustive, of the most relevant teaching strategies to be used in the particular context or situation. The respondents indicated that the following strategies could promote the facilitation of the internalisation of values:

Values clarification, role modelling, role play, the use of electronic and print media, and selfdirected learning/teaching strategies that promote the active participation of the learner and foster lifelong learning.

- The word 'competency' in the document must be used to include the entire domain, such as affective, psychomotor and cognitive. Efforts must be directed at consciously focusing on the affective domain.

\section{Professional values}

- $\quad$ The professional values identified and described must be displayed on walls/notice-boards to create awareness among the college community. Values provide a common language for aligning a nursing service's leadership, education and its people (Smith, 2000:86).

- These professional values must be reviewed regularly and re-emphasised in accordance with the social climate.

\section{Philosophy}

- Values as identified by the task team of the Department of Education must be incorporated into the value system of the nursing college, as these are regarded as being very important to the country during the transformation process.

- An important aspect, namely the Constitution of the country, could also be used as a source of important professional values.

- The Department of Health's mission/vision and philosophy and the SANC's mission/vision statement should form the basis of these values of the nursing college.

- The uniqueness of an individual should be indicated clearly, as this makes provision for respect for all human beings.

\section{Assessment}

- $\quad$ Student assessment should be structured so that mechanisms are built in to focus or give attention to the affective domain. Bloom's taxonomy should be revisited when teaching affective domain issues such as values.

- A concerted effort must be made to ensure that both the formative and summative assessments conducted in the college assess not only the psychomotor and cognitive aspects, but also the affective domain.

- Regular peer review and peer teaching programmes should be developed. A quality 
assurance team should oversee this exercise.

Successful completion of this phase led to the realisation of the purpose and objectives of the study and subsequently answered/addressed the research problem. Recommendations have to be made to improve nursing education and practice, and to suggest further research fields/topics.

\section{RECOMMENDATIONS}

Although most of the appropriate professional values and teaching strategies that facilitate caring in registered nurses are reflected in the college curriculum, these values appear to be neither appropriately taught nor assessed. Even though the nurse educators and student nurses were aware of the appropriate values and teaching strategies to facilitate the internalisation of professional values, as reflected in the curriculum, there was still something missing. It is therefore recommended that for future studies, students should be taught and directed not only to identify the professional values considered to be important for nursing, but also to describe these values, in order to understand them. It has been proven that people's knowledge and understanding of phenomena influence their actions, decisions and attitudes (Jooste, 1998:467).

It is further recommended that guidelines, as discussed in Phase Four, be implemented to improve the education practice currently employed and that nurse educators also use the developed checklist as a self-assessment tool.

\section{Teaching strategies and practice}

Despite the fact that the nurse educators and student nurses are familiar with the appropriate values and teaching strategies that facilitate the internalisation of professional values, this is realised on paper only. The researcher is prompted to ask the following questions, warranting that nurse educators therefore need to review the teaching strategies used in terms of:

- whether the values reflected in the nursing college curriculum receive the attention that they deserve;

- the reason for problems of internalisation of values by students. Could it be because they, the nurse educators, are not role models or moral agents themselves?;

- $\quad$ whether the values that they teach are assessed in both clinical and theoretical settings;

- the possibility of introducing teaching strategies, such as values clarification, early in the programme in order to facilitate caring; and

- their curriculum, and to consider the feasibility of teaching the nurses' pledge early during the course and not to let nurses hear it only much later during the course, or on graduation day.

\section{Nursing research}

The researcher believes that it would be worthwhile to undertake further research in order to answer the question: Why are appropriate professional values and teaching strategies that facilitate caring not implemented by the nurse educators in their teaching when they are familiar with them? Further research could also be carried out about the caring attitudes of the nurse educators towards the student nurses, as it was indicated that for people to be able to care, they too must have experienced for themselves how it feels to be cared for. The competence of the nurse educators to incorporate professional values in their teaching should be explored. This study focused on the role of the nurse educator. Further studies should also focus on other stakeholders or variables involved in the facilitation of professional values among nurses.

\section{CONCLUSION}

This study revealed that both nurse educators and student nurses at the college knew the appropriate values and appropriate teaching strategies that facilitate caring in registered nurses. There were, however, still problems in terms of the internalisation of these values by the students, preventing them from developing into caring registered nurses. It was suggested that the professional values identified for the college should be stipulated clearly and made visible. These should be displayed on the college walls, together with the mission/vision statements of the college, for all the stakeholders, particularly the nurse educators and student nurses, to see.

The findings revealed the need for nurse educators to attend regular in-service training sessions on values education, particularly those who facilitate caring in 
nurses. Nurse educators should act as moral agents, teaching by precept and example, as this has been proven to be the most effective way of teaching students (Jooste, 2001:172).

\section{REFERENCES}

ANDRUSYSZYN, MM 1998: Clinical evaluation of the affective domain. Nurse Education Today, 9:75- 81.

BOOYENS, SW 1998: Dimensions of nursing management; $2^{\text {nd }}$ edition. Kenwyn: Juta.

BRINK, HIL 1990: Teaching caring in nursing. A needs assessment. Curationis, $13(1$ \& 2):38-43.

BRINK HIL 2001: The fundamentals of research methodology for health care professionals. Durban: Butterworths.

CRESWELL, JW 1994: Research design: Qualitative and quantitative approaches. London: Sage.

DEPARTMENT OF NURSING SCIENCE, RAND AFRIKAANS UNIVERSITY 2001: Theory for Health Promotion in Nursing. Johannesburg: Rand Afrikaans University.

DE VOS, AS (Ed.) 1998: Research at grass-roots: A primer for the caring proffessions. Pretoria: Van Schaik.

DE VOS, AS (Ed.) 2001: Research at grass-roots: A primer for the caring proffessions; 3rd impression. Pretoria: Van Schaik.

GIORGI, A 1985: Phenomenology and psychological research. Pittsburgh: Duquesne University.

HAEGERT, S 2001: Dare to care. Nursing Update, July: 28-30. JOOSTE, K 1998: Work motivation (In: SW Booyens (Ed.) 1998: Dimensions of nursing management. Kenwyn: Juta).

JOOSTE, K 2001: Preceptorship in staff development (In: SW Booyens (Ed.) 2001: Introduction to health services management; $2^{\text {nd }}$ edition. Kenwyn:Juta;pp.168-183).

KERLINGER, FN 1986: Foundations of behavioural research. Chicago: Holt, Rinehard \& Winston.

MINNAAR, A 2002: A framework for caring in the leadership process of nurses. Curationis, (25):23-27.

NAUDÉ, M; MEYER, S \& VAN NIEKERK, S 2000: The nursing unit manager. A comprehensive guide. Sandton: Heinemann.

OERMAN, MH 1991: Professional nursing practice: A conceptual approach. Philadelphia: JB Lippincott.

PERA, SA \& VAN TONDER, S 1996: Ethics in nursing practice. Kenwyn: Juta.

QUINN, FM 1995: The principles and practice of nurse education. London: Chapman Hall.

SEARLE, C \& PERA, SA 1993: Professionele praktyk. 'n SuidAfrikaanse verpleegperspektief; 2de uitgawe. Durban: Butterworths. SMITH, S 2000: Inner leadership. Realize your self-leading potential. London: Nicolas Brealey.
STEWARTS, DN \& SHAMDAMSAMI, PN 1990: Focus groups. Theory and practice. London: Sage.

Watson, J 1985: Nursing, human science and human care: A theory of nursing. Norwalk: Appleton.

WEBB, A; PESATA, V; BOWER, DA; GILL, S \& PALLIJA, G 2001: Dimensions of quality care. Perceptions of patients with HIV/AIDS regarding nursing care. Journal of Advanced Nursing, 31(9):414417.

WEIS, DA \& SCHANK, MJ 1995: Towards building an international consensus in professional values. New York: Milwaukee. 